\title{
Sociobiology
}

SHORT NOTE

\section{First Record of Cardiocondyla obscurior Wheeler, 1929 (Hymenoptera: Formicidae: Myrmicinae) for Pakistan}

\author{
Waqar Majeed ${ }^{1}$, Elmo BA Koch², Naureen Rana ${ }^{1}$, Rimsha Naseem ${ }^{1}$
}

1 - Department of Zoology, Wildlife and Fisheries, University of Agriculture Faisalabad, Pakistan

2 - Myrmecology Laboratory, Cocoa Research Center, CEPEC/CEPLAC, Ilhéus-BA, Brazil

\section{Article History}

\section{Edited by}

Evandro Nascimento Silva, UEFS, Brazil

Received

06 October 2020

Initial acceptance

Final acceptance

Publication date

26 February 2021

28 March 2021

13 August 2021

\section{Keywords}

New record, Cardiocondyla; Faisalabad, Gatwala Park.

\section{Corresponding author}

Elmo B.A. Koch (D)

Laboratory of Myrmecology

Cocoa Research Center - CEPEC/CEPLAC

Caixa Postal 7, CEP: 45600-970

Itabuna, Bahia, Brasil.

E-Mail: elmoborges@gmail.com

\begin{abstract}
Ants of the genus Cardiocondyla are considered omnivorous in nature. This genus is native to Afrotropical, Australasia, Indomalaya, Malagasy, Oceania, and Palearctic regions. A total of 72 valid species and 2 valid subspecies has been described worldwide. However, little is known about these ants in Pakistan. As a result of a survey of different sites in the Gatwala park of district Faisalabad during 2018, we collected individuals of the genus Cardiocondy/a. Collected specimens were identified using the most recent and available literature. Prior to current work, only two species of this genus were reported for Pakistan. In this study we added the first record of Cardiocondyla obscurior for Pakistan, followed by a brief description, distribution, and identification key.
\end{abstract}

\section{Introduction}

Pakistan has a total area of $882000 \mathrm{~km}^{2}$ with a world biogeographic realm, including Indo-Malayan, Palearctic, and Afro-Tropical (Cox \& Moore, 1993). The endemism rate is meager; about $7 \%$ flowering plants and $3 \%$ for mammals have been documented (GOP, 1999). Pakistan's ant fauna is highly diverse, with mountainous and desert areas with a low degree of endemism. The worldwide transfer of various organisms through humans is well documented. Due to the development of commerce and improvements in transportations, more species are being transported to their nonnative range of occurrence (Ivanov, 2016). Many Agro-ecological activities are performed by ants such as predators of other arthropods, role in mineralization of nutrients, herbivores, seed dispersal, and increasing soil fertility (Pfeiffer et al., 2013).
Emery originally described the genus Cardiocondyla in 1969. According to Seifert (2003), this is native to Afrotropical, Australasia, Indomalaya, Malagasy, Oceania, and Palearctic regions. A total of 72 valid species and two valid subspecies has been described worldwide (Antweb, 2020). Ants of this genus are commonly found in naturally disturbed sites, wood margin, sand dunes, near the roadside, and often in an environment with less water availability (Seifert, 2003). Workers can be diagnosed based on the following characters; small to minute in size, mandibles with five teeth (variable in size). Clypeus flattened with prominent lateral projection. The antennal segment usually 11-12 with the distinct apical club (3-segmented). Mesosoma forming single connectivity in dorsal view. The propodeal declivity is unarmed to bi-spinose. Pilosity very sparse or absent dorsally (Seifert, 2003). 
A Remarkable contribution to this genus includes Emery (1869); André (1883); Chapman and Capco (1951); Radchenko (1995); MacKay (1995); Rigato (2002); Seifert (2003). Seifert et al. (2017) provided the revisionary work on the genus Cardiocondyla. However, little is known about these ants from Pakistan (Menozzi, 1939; Rasheed et al., 2019). In the present work, we added C. obscurior as a new record for Pakistan's ant fauna.

\section{Materials and Methods}

As a result of a survey of different sites in the Gatwala park of district Faisalabad during 2018, we collected individuals of genus Cardiocondyla manually using a mouth aspirator. The collected material was identified using an N2GG Zoom Stereo Microscope and available literature: Bingham (1903) and Seifert (2003). Identified specimens are housed in Department of Zoology, University of Agriculture Faisalabad ( $\left(31^{\circ} 26^{\prime} 2.18^{\prime \prime} \mathrm{N}, 73^{\circ} 3^{\prime} 53.6^{\prime \prime} \mathrm{E}\right)$.

\section{Results}

Cardiocondyla obscurior Wheeler, 1929

Cardiocondyla wroughtoni var. obscurior Wheeler. 1929: 44 (worker and queen) TAIWAN. Raised to species and senior synonym of bicolor: Seifert, 2003: 271.

Cardiocondyla bicolor Donisthorpe, 1930b: 366 (worker) ISRAEL. Junior synonym of wroughtonii: Kugler, 1984: 6; obscurior: Seifert, 2003: 271.

\section{Material Examined}

Pakistan: 2 workers, 16.v.2018 and 1 worker, 29.v.2018 respectively, in Pakistan, Faisalabad, Gatwala Park, 31 ${ }^{\circ} 25^{\prime} 49.1^{\prime \prime}$

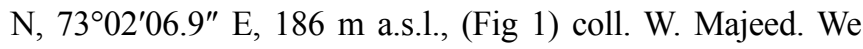
deposited the identified material (voucher number: BL01UAF) in the Biodiversity Laboratory, Department of Zoology, Wildlife and Fisheries, University of Agriculture, Faisalabad.

\section{Description (worker)}

Head shorter, anterior margin narrower while posterior margin slightly broader, sub-rectangular in fullface view, color light brown-dark brownish, antennae yellow, gaster black and highly polished. Metanotal grove present, propodeal spines of moderate size and slightly turned inward at outer face. Antennae 12-segmented with 3 segmented club. Eyes placed just below the middle of head, with smaller post ocular distance. Clypeal margin angulates. Mandibles smaller with minute tooth, apical tooth prominent. Antennal scape shorter, not reaching beyond the vertex; carinae prominent, slightly divergent laterally. Pilosity: Head, mesosoma, petiole and postpetiole with minute, whitish and decumbent hairs in profile view. Head, mesosoma, and waist brightly yellowish or yellowish brown.

Key to the Pakistani species of the ant genus Cardiocondyla based on worker caste

1. Body yellow-light yellowish brown; body length $<2 \mathrm{~mm}$; propodeal declivity with short and acute spines.

.2

- Body light brown-black brown; body length $>2 \mathrm{~mm}$;

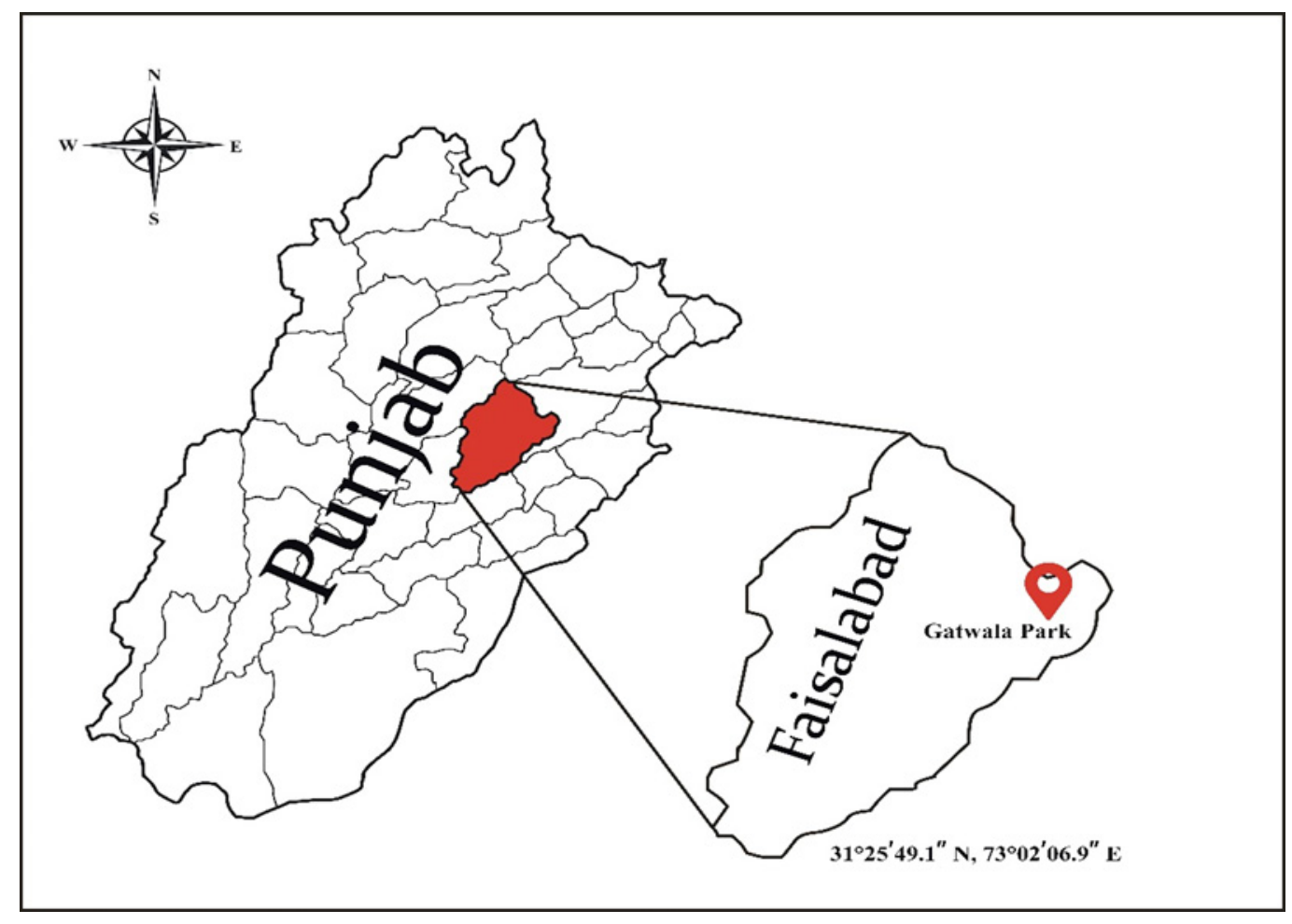

Fig 1. Geographical record of C. obscurior in Gatwala Faisalabad, Pakistan. 
propodeal declivity with tubercles in lateral......Cardiocondyla mauritanica

2. Petiole trapezoidal dorsally; mesosoma with fine sculptured, the area near the propodeal spines having minute and irregular sculptures in dorsal................Cardiocondyla wroughtonii - Petiole globose; mesosoma with irregular and minute sculptured throughout in dorsal......Cardiocondyla obscurior

\section{Ecology}

The C. obscurior individuals were observed on small and large shrubs and herbs, shrubs, and the leaf litter for nesting. However, few workers were observed while they were foraging on small grasses and flowers.

\section{Global Distribution}

Canary Island, Germany, Israel, Kenya, India, Nepal, Japan, Taiwan, Hawai, Mariana Island, Brazil, Puerto Rico, Virgin Island, Florida (Seifert, 2003).

\section{Discussion}

C. obscurior is considered as cosmopolitan species of Indomalayan region. Some of the species of Cardiocondyla genus were recorded previously as mentioned above in results (Rasheed et al., 2019) from Pakistan, but the genus Cardiocondyla and other species of the Formicidae family were published with a major extension of species record from India (Bharti, 2016; Bharti \& Kumar, 2017). This species mostly found in urban areas/outdoors localities (SanchezGarcia \& Espadaler, 2015; Trigos-Peral \& Reyes-Lopez, 2016; Ivanov, 2016), while Seifert (2003), Boer et al. (2018), as well as Espadaler and Nilo (2019) found these species as indoor in France, The Netherlands and Spain, respectively. Many types of tramp ants have been dispersed worldwide, found in our plant materials, packing materials, construction supplies and heavy machines like logging. In certain places they invaded, some of these animals had large population disturbances, which caused severe ecological and economic challenges (Wetterer, 2012).

The species is considered an accomplished tramp ant (Heinze et al., 2006) and has established populations across the world, including northern Europe (Rasplus et al., 2010; Seifert, 2003), but it is not considered a pest nor known to affect native ecosystems adversely. Moreover, it seemed like this species has a social system similar to unicoloniality and is non-informative either in one-to-one experiments (Heinze et al., 2006). The restriction of the two non-tramp ants in the $C$. wroughtonii group to India and Borneo suggests the native range of C. obscurior to be Southeast Asia. C. obscurior is polygynous and often founds new colonies by nest splitting (Seifert, 2003).

According to the present study results, we believe that the occurrence of $C$. obscurior in Pakistan should not be trivial. The lack of records in the literature is probably associated with the lack of studies in the group, and probably more records for the species should be pointed out with the development of future research.

\section{Acknowledgment}

The authors would like to thank the University of Agriculture for conducting and supporting this research. We also acknowledge Muhammad Tariq Rasheed (Department of Entomology, PMAS Arid Agriculture University, Rawalpindi) for helping in identification and manuscript revision.

\section{Authors' contribution}

WM: conceptualization, methodology, investigation, material identification, writing $\&$ revision.

EBAK: conceptualization, methodology, writing \& revision. NR: conceptualization, methodology, writing \& revision $\mathrm{RN}$ : conceptualization, methodology, material identification, writing \& revision.

\section{Conflict of interests}

The authors declare that they have no conflict of interest.

\section{References}

André, E. (1883). Les fourmis. Species des Hyménoptères d'Europe et d'Algérie. Tome Deuxième. Beaune. 919 + 48 p.

Antweb. (2020). California Academy of Science, online at https://www.antweb.org (Accessed 5 Jan 2020).

Bharti, H., Wachkoo, A.A. \& Kumar, R. (2017). First inventory of ants (Hymenoptera: Formicidae) in northwestern Shivalik, India. Halteres 8: 33-68.

Bharti, H., Guénard, B., Bharti, M. \& Economo, E.P. (2016). An updated checklist of the ants of India with their specific distributions in Indian states (Hymenoptera, Formicidae). ZooKeys, 551: 1-83. doi: 10.3897/zookeys.551.6767

Bingham, C.T. (1903). The Fauna of British India, including Ceylon and Burma. Hymenoptera: Ants and Cuckoo Wasps, Vol. II. Taylor and Francis, London, 506 pp.

Boer, P., Noordijk, J., Heijerman, T., Verhoogt, K. \& Van Vugt, R. (2018). De tweekleurige hartknoopmier, Cardiocondyla obscurior, in de Hortus Botanicus Leiden (Hymenoptera: Formicidae). Entomologische Berichten, 78: 10-15.

Chapman, J.W. \& Capco, S.R. (1951) Check list of the ants (Hymenoptera: Formicidae) of Asia (No. 1). Bureau of Print.

Clavero, M. \& Garcia-Berthou, E. (2005). Invasive species are a leading cause of animal extinctions. Trends in Ecology and Evolution, 20: 110. doi: 10.1016/j.tree.2005.01.003 
Cox, C. B. \& Moore, P.O. (1993). Biogeography: An Evolutionary Approach. London: Blackwell Scientific.

Emery, C. (1869). Enumerazione dei Formicidi che rinvengonsi nei contorni di Napoli. Annali della Accademia degli Aspiranti Naturalisti, 2: 1-26.

Espadaler, X. \& Nilo, O.Z. (2019). Cardiocondyla obscurior Wheeler, 1929 (Hymenoptera: Formicidae) in Catalonia (NE Spain), with comments on exotic ant species. Butlleti de la Instituci Catalana d'Historia Natural, 83: 153-156. doi: $10.2436 / 20.1502 .01 .21$

Government of Pakistan - G.O.P. (1999). Biodiversity Action Plan of Pakistan. Ministry of Environment/ IUCN/WWF. Islamabad.

Heinze, J., Cremer, S., Eckl, N. \& Schrempf, E. (2006). Stealthy invaders: the biology of Cardiocondyla tramp ants. Insectes Sociaux, 53: 1-7. doi: 10.1007/s00040-005-0847-4

Ivanov, K. (2016). Exotic ants (Hymenoptera: Formicidae) of Ohio. Journal of Hymenoptera Research, 51: 203-226. doi: $10.3897 / \mathrm{jhr} .51 .9135$

Mackay, W. P. (1995). New distributional records for the ant genus Cardiocondyla in the New World (Hymenoptera: Formicidae). Pan Pacific Entomologist, 71: 169-172.

Menozzi, C. (1939). Formiche dell'Himalaya e del Karakorum raccolte dalla Spedizione italiana comandata da S. A. R. il Duca di Spoleto (1929). Atti della Societa Italiana di Scienze Naturali e del Museo Civico di Storia Naturale Milano, 78: 285-345.

Pfeiffer, M., Mezger, D. \& Dyckmans, J. (2013). Trophic ecology of tropical leaf litter ants (Hymenoptera: Formicidae) - a stable isotope study in four types of Bornean rain forest. Myrmecological News, 19: 31-41.

Radchenko, A. (1995). Palearctic ants of the genus Cardiocondyla Emery (Hymenoptera, Formicidae). Entomologicheskoe Obozrenije, 2: 447-455.
Rasheed, MT, Bodlah, I., Fareen, A.G., Wachkoo, A.A., Huang, X., \& Akbar, S.A. (2019). A Checklist of Ants (Hymenoptera: Formicidae) in Pakistan. Sociobiology, 66: 426-439. doi: 10.13102/sociobiology.v66i3.4330

Rasplus, J. Y., Villemant, C., Paiva, M. R., Delvare, G., \& Roques, A. (2010). Hymenoptera. Chapter 12. BioRisk, 4: 669.

Rigato, F. (2002). Three new Afrotropical Cardiocondyla Emery, with a revised. Bollettino della Societá Entomológica d'Italia, 34: 167-173.

Sanchez-Garcia, D. \& Espadaler, X. (2015). Cardiocondyla obscurior Wheeler, 1929 (Hymenoptera: Formicidae) en España. Iberomyrmex, 7: 7-9.

Seifert, B. (2003). The ant genus Cardiocondyla (Insecta: Hymenoptera: Formicidae) - a taxonomic revision of the C. elegans, C. bulgarica, C. batesii, C. nuda, C. shuckardi, C. stambuloffi, C. wroughtonii, C. emeryi, and C. minutior species groups. Annalen des Naturhistorischen Museums in Wien. Serie B, Für Botanik und Zoologie, 104: 203-338.

Seifert, B., Okita, I. \& Heinze, J. (2017) A taxonomic revision of the Cardiocondyla nuda group (Hymenoptera: Formicidae). Zootaxa, 4290: 324-356. doi: 10.11646/zootaxa.4290.2.4

Trigos-Peral, G. \& Reyes-Lopez, J. (2016) Quite a cosmopolitan neighborhood: A new record of Cardiocondyla obscurior Wheeler, 1929 together with Cardiocondyla mauritanica Forel, 1890 and Linepithema humile (Mayr, 1868) (Hymenoptera, Formicidae). Boletín de la Asociacion Española de Entomología, 40: 503-506.

Wetterer, J.K., Kronauer, D.J.C. \& Borowiec, L. (2012) Worldwide spread of Cerapachys biroi (Hymenoptera: Formicidae: Cerapachyinae). Myrmecological News, 17: 1-4.

Wheeler, W.M. (1929). Ants collected by Professor F. Silvestri in Formosa, the Malay Peninsula and the Philippines. Bollettino del Laboratorio di Zoologia Generale e Agraria della Reale Scuola Superiore d' Agricoltura Portici, 24: 27-64.

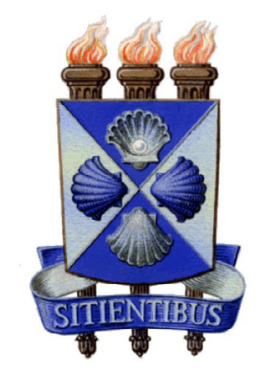

